\title{
BEHAVIOR OF PANTANEIRA AND GIROLANDO HEIFERS REARED ON PASTURES IN THE FOUR SEASONS OF THE YEAR ${ }^{1}$
}

\author{
PEDRO GUSTAVO LOESIA LIMA ${ }^{2} *$, MARCUS VINICIUS MORAIS DE OLIVEIRA ${ }^{3}$, MARCIO GREGÓRIO ROJAS \\ DOS SANTOS $^{3}$, KHEYCIANE VIANA DA SILVA ${ }^{3}$, VITÓRIA SOARES ${ }^{3}$
}

\begin{abstract}
The objective of this study was to evaluate feeding and physiological dynamics of Pantaneira and Girolando heifers reared on pasture and their preference for three types of natural shadows. Fourteen animals, seven of each breed, with mean weight of $328 \mathrm{~kg}$ (Pantaneira) and $430 \mathrm{~kg}$ (Girolando) were used. The pasture consisted of Panicum maximum; the animals' behavior in open areas and under treetops (Anadenanthera colubrina; Terminalia argentea, and Mangifera indica) was evaluated. Two 24-hour observations were performed per station, totaling 192 hours of data collection. The experimental design was completely randomized, using $4 \times 2 \times 3$ (station $\times$ breed $\times$ canopy) and $4 \times 2$ (station and breed) factorial arrangements, with 7 replications. $M$. indica was the preferred tree species by both breeds in all seasons; Girolando animals remained longer under the canopy of these trees during winter and spring. Feeding dynamics of the two breeds was similar, with a seasonal effect on the standing rumination (SR) variables and social interaction, with Girolando spending more SR time in the spring (230.0 min) and less interaction in the summer $(53.57 \mathrm{~min})$. Girolando animals searched for water more often during summer. No statistical differences or interactions between factors were found for urination and defecation of the animals, except for defecation in the summer period, which was higher than in the other seasons.
\end{abstract}

Keywords: Naturalized cattle. Animal comfort. Ethology. Shadow.

\section{COMPORTAMENTO DE NOVILHAS PANTANEIRA E GIROLANDO CRIADAS EM PASTAGENS NAS QUATRO ESTAÇÕES DO ANO}

RESUMO - O objetivo deste estudo foi avaliar a dinâmica alimentar e fisiológica de novilhas Pantaneira e Girolando criadas em pastagem e a preferência por três tipos de sombras naturais. Foram utilizados 14 animais, sete de cada raça, com peso médio de $328 \mathrm{~kg}$ (Pantaneira) e $430 \mathrm{~kg}$ (Girolando). O pasto consistia em Panicum maximum. Foi avaliado o comportamento dos animais em áreas abertas e sob as copas das árvores (Anadenanthera colubrina; Terminalia argentea e Mangifera indica). Duas observações de 24 horas foram realizadas por estação, totalizando 192 horas de coleta de dados. O delineamento experimental foi inteiramente casualizado, utilizando arranjos fatorial $4 \times 2 \times 3$ (estação $\times$ raça $\times$ copa) e $4 \times 2$ (estação e raça), com 7 repetições. $M$. indica foi a espécie arbórea preferida pelas duas raças em todas as estações. Os animais Girolando permaneceram mais tempo sob o dossel das árvores durante o inverno e a primavera. A dinâmica alimentar das duas raças foi semelhante, com efeito sazonal nas variáveis de ruminação em pé (RP) e interação social, com Girolando gastando mais tempo de RP na primavera (230,0 min) e menor interação no verão (53,57 min). Animais Girolando procuraram por água com mais frequência durante o verão. Não foram encontradas diferenças estatísticas ou interações entre fatores para micção e defecação dos animais, exceto para a defecação no período de verão, que foi maior que nas demais estações.

Palavras-chave: Gado naturalizado. Conforto animal. Etologia. Sombra.

\footnotetext{
"Corresponding author

${ }^{1}$ Received for publication in $05 / 25 / 2018$; accepted in $04 / 22 / 2019$.

Paper extracted from the scientific initiation work of the first author.

${ }^{2}$ Department of Animal Sciences, Universidade Estadual de Maringá, Maringá, PR, Brazil; pedroloesia@gmail.com - ORCID: 0000-00025319-5409.

${ }^{3}$ Department of Animal Sciences, Universidade Estadual de Mato Grosso do Sul, Aquidauana, MS, Brazil; marcusvmo@yahoo.com.br ORCID: 0000-0002-3388-6050, mgrsantos25@gmail.com - ORCID: 0000-0001-6518-7927, kheycianeviana@gmail.com - ORCID: 00000002-4873-3364, v.vitoriasoares@hotmail.com - ORCID: 0000-0003-4945-6052.
} 


\section{INTRODUCTION}

Thermal exchange by convection is an important thermoregulation mechanism for ruminants, which makes thermal homeostasis possible. However, this mechanism depends on energy exchange, which occurs between the surface temperature of the animal's fur and the air temperature in the environment (TRIPON et al., 2014; DE OLIVEIRA et al., 2018; RASHAMOL et al., 2018). Thus, when the external temperature is high, this mechanism becomes ineffective and the animals are subjected to a thermal stress, with profound physiological and behavioral changes and significant reduction in food consumption and zootechnical performance. Shadowed areas are required for animals, even in regions with average temperatures below $24{ }^{\circ} \mathrm{C}$, to mitigate the negative effects of ultraviolet rays; these shadows can be natural or artificial (RODRIGUES; SOUZA; PEREIRA FILHO, 2010; KARVETTE et al., 2016).

Ethological evaluations are important when evaluating changes in behavioral patterns of animals focused on climatic changes, especially food intake, since it is directly affected by the air temperature and is directly correlated to the animals' performance. Grazing time is affected by food availability and nutritional quality, physiological need of the animal, stress level, and presence of parasites and diseases (FACURI et al., 2014).

Pantaneiro cattle were introduced to the Pantanal biome, in the State of Mato Grosso do Sul, Brazil, hundreds of years ago by Spanish and Portuguese during the South America colonization. According to Oliveira et al. (2015), this breed underwent a natural selection process, which gave them high rusticity, mainly regarding their capacity to withstand high temperatures, periods of intermittent drought and flooding, ectoparasites and endoparasites, and seasonal variations in the quality of forage resources.

Thus, behavioral studies on Pantaneiro cattle are important, because of scarcity of technical information about this breed and its current risk of extinction; approximately 500 pure individuals are kept in government conservation centers and some private farms. The loss of a breed, such as the Pantaneira, is an irreversible damage to the world's science and livestock, since these animals carry singular and desirable genes for animal production (DANI; OLIVEIRA, 2013).

Girolando cattle originated from the crossing between Gir and Holstein animals; it is characterized as a synthetic breed of Brazilian genetic heritage. It contributed significantly to the strength of national dairy cattle; the physiological and morphological characteristics of these animals are suited to the tropics, presenting excellent body shape, good fur pigmentation, high capacity of self-regulation of body heat, and high grazing efficiency; which gives them great resistance, adequate adaptability to the environment, and a high performance.

Therefore, the objective of this study was to evaluate feeding and physiological dynamics of Pantaneira and Girolando heifers reared on pasture in the four seasons of the year and their preference for three types of natural shadows in the High Pantanal region, in Mato Grosso do Sul, Brazil.

\section{MATERIAL AND METHODS}

The experiment was carried out at the Milk Excellence Center of Mato Grosso do Sul, of the Universidade Estadual de Mato Grosso do Sul (UEMS), in Aquidauana, MS, Brazil $\left(20^{\circ} 27^{\prime} \mathrm{S}\right.$, $55^{\circ} 40^{\prime} \mathrm{W}$, and altitude of 167 meters). According to the classification of Köppen, the region presents a tropical climate of Savanna with dry winter (aw).

Fourteen heifers - seven Pantaneira and seven Girolando $(3 / 4$ Holstein $x \quad 1 / 4$ Gir $)$-with approximately 18 months and weights of $328 \pm 14 \mathrm{~kg}$ and $430 \pm 28 \mathrm{~kg}$, respectively, were used. All animals were identified with an earring and kept together in a 6-hectare Panicum maximum pasture area divided into paddocks and managed in a rotational system. The heifers were treated prophylactically against endo/ectoparasites and had water and mineral salt ad libitum.

Although pasture was rotated, the animals were observed always in the same paddock; this paddock had natural shading by three trees speciesAnadenanthera colubrina (CP1), Terminalia argentea (CP2), and Mangifera indica (CP3).

Mangifera indica is an arboreal species that can solve the thermal environmental problems that affects animals in the tropics; its canopy provides significant welfare to the animals due to the its pleasant microclimate by its dense foliage and wide shade (LOUREIRO; BARBOSA, 2010). Terminalia argentea is a tree species that colonizes low fertility soil, produces wood, but generates small shade (OTSUBO et al.,2015). Anadenanthera colubrina is a typical species of the Cerrado biome; it has a scattered canopy, small leaves, and arched branches that facilitate the passage of light and increase the incidence of solar radiation under the canopy, raising the temperature in this microclimate. According to Nepomuceno et al. (2007), this is a deciduous species, presenting falling of leaves during the dry season as a physiological adaptation mechanism.

Feeding and physiological dynamics were evaluated according to a methodology adapted from Garry, Sherritt and Hale(1970) and Oliveira et al. (2015), with observations made in the four seasons of the year. Two 24-hour observations were made in each season of the year, totaling eight observations, beginning at 6:00 a.m., totaling 192 hours of observation. The data were organized in spreadsheets developed for behavioral tests. Collection was made 
by trained evaluators, four at a time, in a relay system, positioned strategically to not disturb the animals and interfere with their behavior. The animals' body temperature (BT) was checked with one-hour intervals using a digital infrared thermometer. Nighttime observations were performed using night vision binoculars.

Feeding dynamics was evaluated using the parameters: standing rumination (SR), which represents the dynamics of the food after regurgitation when the animal is standing; lying down rumination (LDR), which is the same as SR, but when the animal is laid down; sleeping on foot (SF), when the animal is standing and with eyes closed and is not ruminating; sleeping lying down (SD), when the animal is laid down with eyes closed and is not ruminating; leisure state (LS), when the animal does not present any type of action; eating (EAT), which comprises the movements of food intake; and social interaction (INT), when the animal is not ruminating, eating, idling, urinating, defecating, or ingesting water, but in any activity of movement or social interaction.

The parameters considered for the physiological dynamics were the number of times the animals ingest water, defecate, and urinate within the evaluation period.
The preference of the animals for the different trees for shade was determined by summing the time they spend during the day in the shadows with the time they stay under the treetops at night.

In each period of observation, forage samples were collected using a simulated grazing technique. The grass was collected for 40 minutes, starting at 7:00 a.m. The evaluators followed the animals, keeping a distance lower than 2 meters, to observe the grazing habit of the heifers and their preference for the structural components of the forages. After homogenizing the material, a sample of $500 \mathrm{~g}$ was stored in a freezer $\left(-20{ }^{\circ} \mathrm{C}\right)$ and, then, used to determine partial dry matter, final dry matter, crude protein, neutral detergent fiber, and acid detergent fiber (PROHMANN et al., 2012). The availability of forage biomass was determined by the square frame technique, in which a square frame is randomly launched at the paddocks and the grass sample encompassed is collected with cutting close to the ground and immediately weighed for quantification.

Data on air temperature and relative humidity were collected with 60-minute intervals, using portable digital devices positioned at full sun and under tree shades during the day, and at the open field and under the treetops at night (Table 1).

Table 1. Maximum and minimum air temperature and humidity obtained at the open field and under canopies of the different tree species, during 24-hour periods.

\begin{tabular}{|c|c|c|c|c|c|c|c|c|c|}
\hline \multirow{2}{*}{ Seasons } & \multirow{2}{*}{ Index } & \multicolumn{4}{|c|}{ Temperature $\left({ }^{\circ} \mathrm{C}\right)$} & \multicolumn{4}{|c|}{ Humidity (\%) } \\
\hline & & Open field $^{1}$ & ${\text { Canopy } \mathrm{A}^{2}}^{2}$ & Canopy B $^{3}$ & Canopy $\mathrm{C}^{4}$ & Open field $^{1}$ & Canopy A $^{2}$ & Canopy B $^{3}$ & Canopy $\mathrm{C}^{4}$ \\
\hline \multirow[t]{2}{*}{ Winter } & Maximum & 32.8 & 32.8 & 32.5 & 33.0 & 92 & 92 & 92 & 92 \\
\hline & Minimum & 16.8 & 18.6 & 18.0 & 18.5 & 51 & 53 & 54 & 56 \\
\hline \multirow[t]{2}{*}{ Spring } & Maximum & 39.2 & 38.4 & 38.0 & 37.0 & 81 & 69 & 78 & 80 \\
\hline & Minimum & 24.9 & 20.1 & 25.1 & 24.9 & 42 & 41 & 44 & 45 \\
\hline \multirow[t]{2}{*}{ Summer } & Maximum & 44.1 & 38.9 & 37.2 & 35.0 & 91 & 88 & 89 & 90 \\
\hline & Minimum & 21.3 & 23.8 & 23.2 & 22.4 & 40 & 44 & 44 & 43 \\
\hline \multirow[t]{2}{*}{ Autumn } & Maximum & 37.8 & 35.2 & 36.8 & 34.2 & 92 & 92 & 92 & 90 \\
\hline & Minimum & 20.1 & 22.5 & 22.2 & 21.8 & 41 & 41 & 40 & 46 \\
\hline
\end{tabular}

${ }^{1}$ Any area in the paddocks, except under the treetops; ${ }^{2}$ Anadenanthera colubrina; ${ }^{3}$ Terminalia argentea $;{ }^{4}$ Mangifera indica .

The canopy type of the trees was compared using a completely randomized design in a $4 \times 2 \times 3$ factorial arrangement (season $\times$ breed $\times$ tree species) with 7 replications; the animals were the experimental units. The animal behavior was compared using a completely randomized design in a $4 \times 2$ factorial arrangement (station $\times$ breed) with 7 replications, and the animals were the experimental units. The data were evaluated using the $\mathrm{R}$ 3.3.0 statistical program (R Core Team, 2016), with a significance level of 5\%. The means were compared through the Tukey's test at 5\% probability level.

\section{RESULTS AND DISCUSSION}

The nutritional quality of the grass used (Panicum maximum) varied throughout the year. The highest biomass production was found in the wet period, with maximum yield in the summer $\left(6,403.34 \mathrm{~kg} \mathrm{ha}^{-1}\right)$ and a higher leaf to stem ratio in the spring. The lowest values of protein were found in the autumn and winter; forage yield and acid detergent fiber (ADF) concentration decreased during this dry period, increasing the lignification of the grass (Table 2).

According to Van Soest (1994), protein levels lower than $7 \%$ and high $\mathrm{ADF}$ are undesirable because they limit ruminal microbial fermentation 
and reduce animal consumption. Gregorini et al. (2011) reported that feed availability and nutritional quality directly affect the feeding dynamics of grazing cattle, and an increase in the bit rate and time spent on grazing is frequently observed in the animals in periods of low forage availability.

Table 2. Chemical composition of the dry matter of Panicum maximum cv. Mombaça and its leaf, stem, and senescent material fractions in the four seasons.

\begin{tabular}{ccccc}
\hline Variables & Spring & Summer & Autumn & Winter \\
\hline Dry Matter - \% & 24.2 & 24.8 & 24.7 & 26.6 \\
Crude Protein - \% & 7.4 & 7.8 & 4.3 & 4.2 \\
Neutral Detergent Fiber - \% & 69.5 & 69.5 & 64.0 & 69.9 \\
Acid Detergent Fiber - \% & 47.6 & 46.9 & 48.1 & 53.3 \\
Ash - \% & 9.1 & 9.3 & 10.5 & 10.6 \\
Production DM - kg/hectare & $4,279.8$ & $6,403.3$ & $4,006.9$ & $3,731.3$ \\
Leaf - \% & 67.0 & 68.0 & 53.0 & 50 \\
Stem - \% & 21.0 & 25.0 & 30.0 & 32 \\
Senescent Material - \% & 12.0 & 7.0 & 17.0 & 18 \\
Sheet/stem ratio & 3.2 & 2.7 & 1.8 & 1.6 \\
\hline
\end{tabular}

The factors (station $\mathrm{x}$ breed $\mathrm{x}$ shading) presented significant interactions. The season of the year, type of shading, and breed of the heifers affected the animals shade choice. Girolando animals remaining in shades of Mangifera indica in the spring during $64.7 \%$ of the 24 hours daily (932.8 min) (Table 3). Karvette et al. (2016) reported that the tree canopy can reduce by up to $28.3 \%$ the thermal radiation load. According to Biavatti, Berber and Berber (2014), shade in grazing paddocks decreases the animals' thermal stress by providing a better thermal comfort, and increase the animal production.

According to Silva et al. (2012), Girolando animals need shaded environments; they found a decrease of $2.5 \mathrm{~kg}$ in milk yield when Girolando cows were not provided with shades for two hours prior to milking. Carvalho et al. (2018) compared Girolando animals on grazing systems and, as in the present work, found that $3 / 4$ Holstein $\times 1 / 4$ Gyr animals are less heat tolerant than $1 / 2$ Holstein $\times 1 / 2$ Gyr animals.

Table 3. Unfolding of the interaction (Station $\times$ Breed $\times$ Shading) for preference of trees (Anadenanthera colubrina, Terminalia argentea, and Mangifera indica) for shading.

\begin{tabular}{llccl}
\hline \multirow{2}{*}{ Season } & Breed & & Shading $\left(\right.$ min day $\left.{ }^{-1}\right)$ & \\
\cline { 3 - 4 } & & A. colubrina & T. argentea & . indica \\
\hline \multirow{2}{*}{ Winter } & Pantaneira & $33.6 \mathrm{bB}$ & $19.3 \mathrm{aB}$ & $366.4 \mathrm{eA}$ \\
& Girolando & $12.8 \mathrm{bB}$ & $62.1 \mathrm{aB}$ & $461.4 \mathrm{dA}$ \\
\multirow{2}{*}{ Spring } & Pantaneira & $35.7 \mathrm{bB}$ & $5.0 \mathrm{aB}$ & $824.3 \mathrm{bA}$ \\
& Girolando & $37.1 \mathrm{bB}$ & $19.3 \mathrm{aB}$ & $932.8 \mathrm{aA}$ \\
\multirow{2}{*}{ Summer } & Pantaneira & $42.8 \mathrm{abB}$ & $20.0 \mathrm{aB}$ & $605.0 \mathrm{cA}$ \\
& Girolando & $132.1 \mathrm{aB}$ & $40.7 \mathrm{aC}$ & $690.0 \mathrm{cA}$ \\
& Pantaneira & $17.8 \mathrm{bB}$ & $15.7 \mathrm{aB}$ & $342.8 \mathrm{eA}$
\end{tabular}

${ }^{1}$ Means followed by the same lowercase letters in the columns or uppercase letters in the rows do not differ by the Tukey's test at $5 \%$ probability level.

The interaction between the factors (station $x$ breed) was not significant for time of permanence at the open field and under treetops (Table 4).

Several studies on the cattle performance on pastures have been developed in the CerradoPantanal ecotone region, but many consider that this region has only two well-defined seasons, dry (June to October) and rainy (November to May) (PAULA et al., 2010; VILELA et al., 2011; DE MORAES,
2012). These studies disagree with the findings of the present work about the animals' behavior and search for shadow.

The permanence time of Pantaneira and Girolando heifers at the open field and under the treetops presented significant difference in the four seasons of the year. During autumn and winter, the animals remained at the open field for an average of $1,044.64$ and $962.14 \mathrm{~min}$, totaling $72.5 \%$ and $66.8 \%$ 
of the time, respectively. The greatest demand for shade was in the summer $(\mathrm{P}<0.05)$ with mean time spent of $927.14 \mathrm{~min}$, representing $64.4 \%$ of the time (Table 4).

Baliscei et al. (2013) reported that silvopastoral systems make the environment more harmonic because they reduce the climatic differences between seasons. Leme et al. (2005) evaluated the time spent in the sun or shade by Holstein-Zebu cows in a silvopastoral system and found that the animals remain $14.9 \%$ longer in the sun during winter, and $37.2 \%$ longer in the shade during summer.

The breed affected the time the Pantaneiros animals stayed at the open field, which was 118.57 min longer (59.6) $(\mathrm{P}<0.05)$ than the Girolando
(51.3\%) (Table 4). This confirms the lower demand for shade of Pantaneira cattle for thermoregulation and denotes its ability to remain longer at the open field in face of climatic variations throughout the year. The greater tolerance of Pantaneira heifers to sun exposure is explained by their natural selection throughout the years in which the breed was introduced in the Brazilian Pantanal region, which gave them greater rusticity and adaptation to the heat (DANI; OLIVEIRA, 2013).

Bos indicus breeds regulate body temperature better than Bos taurus (LESS, et al., 2018). Pantaneiros cattle are Bos taurus animals (BARBOSA, et al., 2014), but they were superior to the Girolando, which is $1 / 4$ of Bos indicus.

Table 4. Permanence time of Pantaneira and Girolando heifers at the open field and under the treetops in the four seasons of the year.

\begin{tabular}{ccc}
\hline Season & Open field $^{1}(\mathrm{~min} /$ day) & Total Canopy $^{2}(\mathrm{~min} /$ day) \\
\hline Winter & $962.2 \mathrm{a}$ & $477.8 \mathrm{c}$ \\
Spring & $512.8 \mathrm{c}$ & $927.2 \mathrm{a}$ \\
Summer & $674.6 \mathrm{~b}$ & $765.4 \mathrm{~b}$ \\
Autumn & $1,044.6 \mathrm{a}$ & $395.4 \mathrm{c}$ \\
\hline Breed & & \\
Pantaneira & $857.9 \mathrm{a}$ & $582.1 \mathrm{~b}$ \\
Girolando & $739.3 \mathrm{~b}$ & $700.7 \mathrm{a}$ \\
\hline Interaction & P value & P value \\
Season $\times$ Breed & $>0.05$ & $>0.05$ \\
Coefficient of Variation $(\%)$ & 11.34 & 14.12 \\
\hline
\end{tabular}

Means followed by the same lowercase letters in the columns do not differ by the Tukey's test at 5\% probability level; ${ }^{1}$ Any area in the paddocks, except under the treetops; ${ }^{2}$ Sum of the permanence time under the treetops of Anadenanthera colubrina; Terminalia argentea, and Mangifera indica.

The interactions between the factors were not significant for body temperature variables (Table 5). The lowest body temperatures were found in the winter and there was no difference between breeds. According to Shiota et al. (2013), the seasons affect physiological parameters of the animals; they found significant differences in body temperature in Nellore heifers managed in grazing systems in winter and summer, with averages of 35.9 and $37.3{ }^{\circ} \mathrm{C}$, respectively.

Barbosa et al. (2014) reported that the fur temperature is affected by air temperature, but found no significant differences between Red Nelore, Nelore, and Pantaneira breeds. The Pantaneiro cattle have a less thick fur and higher percentage of sweat glands tissues and, consequently, a higher transpiration rate than Holstein cattle (BIANCHINI et al., 2006), thus, they can maintain thermal homeostasis with greater efficiency. However, the lack of significant differences between breeds in the present study can be attributed to the degree of Zebu blood of the Gir breed in the Girolando animals. The neck, upper front leg, and croup temperatures of Pantaneiro animals were $30.7,32.6$, and $31.9{ }^{\circ} \mathrm{C}$ respectively. Similar results were found by Barbosa et al. (2014) $-33.6{ }^{\circ} \mathrm{C}$ for neck, $33.7{ }^{\circ} \mathrm{C}$ for rib, and $34.3{ }^{\circ} \mathrm{C}$ for croup.

Among the variables of feeding dynamics, the interactions between the factors were significant for the standing rumination (SR) and social interaction (Tables 6 and 7).

The seasons of the year had no effect on lying down rumination, sleeping on foot, lying down sleeping, and eating. The longest time for leisure was found in spring, with $341.78 \mathrm{~min} \mathrm{day}^{-1}$, representing $23 \%$ of the daily time (Table 6 ). 
P. G. L. LIMA et al.

Table 5. Surface body temperature of Pantaneira and Girolando heifers in different seasons of the year.

\begin{tabular}{ccccc}
\hline Variables & Neck $\left({ }^{\circ} \mathrm{C}\right)$ & Upper front leg $\left({ }^{\circ} \mathrm{C}\right)$ & Croup $\left({ }^{\circ} \mathrm{C}\right)$ & Average* $\left({ }^{\circ} \mathrm{C}\right)$ \\
\hline Season & & & & \\
Winter & $28.21 \mathrm{~b}$ & $29.21 \mathrm{~b}$ & $28.36 \mathrm{~b}$ & $28.59 \mathrm{~b}$ \\
Spring & $31.51 \mathrm{a}$ & $31.90 \mathrm{a}$ & $31.37 \mathrm{a}$ & $31.60 \mathrm{a}$ \\
Summer & $32.09 \mathrm{a}$ & $32.56 \mathrm{a}$ & $31.90 \mathrm{a}$ & $32.17 \mathrm{a}$ \\
Autumn & $31.23 \mathrm{a}$ & $31.70 \mathrm{a}$ & $30.79 \mathrm{a}$ & $31.24 \mathrm{a}$ \\
\hline Breed & & & & \\
Pantaneira & $30.72 \mathrm{a}$ & $31.40 \mathrm{a}$ & $30.81 \mathrm{a}$ & $30.98 \mathrm{a}$ \\
Girolando & $30.79 \mathrm{a}$ & $31.26 \mathrm{a}$ & $30.40 \mathrm{a}$ & $30.81 \mathrm{a}$ \\
\hline & & & & \\
\hline Interaction & P value & P value & P value & P value \\
Season*Breed & $>0.05$ & $>0.05$ & $>0.05$ & $>0.05$ \\
Coefficient of Variation $(\%)$ & 7.23 & 7.3 & 8.61 & 7.58 \\
\hline
\end{tabular}

*Average of neck, upper front leg, and croup temperatures. Means followed by the same lowercase letters in the column do not differ by the Tukey' test at $5 \%$ probability level.

Tripon et al. (2014) evaluated similar variables in the winter and summer times an found effect of the season on dairy calf behavior, including lying down, resting, standing up, feeding, rumination, drinking, and self-grooming; the total eating period was shorter in winter $(442.1 \mathrm{~min})$ when compared to the summer $(543.5 \mathrm{~min})$.

Table 6. Feeding dynamics (minutes per day) of Pantaneira and Girolando heifers in the different seasons of the year.

\begin{tabular}{|c|c|c|c|c|c|c|c|}
\hline Variables & SR & LDR & $\mathrm{SF}$ & $\mathrm{SD}$ & $\mathrm{LS}$ & EAT & INT \\
\hline \multicolumn{8}{|l|}{ Season } \\
\hline Winter & $142.1 \mathrm{ab}$ & $285.4 \mathrm{a}$ & $7.5 \mathrm{a}$ & $74.3 \mathrm{a}$ & $250.4 \mathrm{ab}$ & $595.7 \mathrm{a}$ & $84.6 \mathrm{a}$ \\
\hline Spring & $195.0 \mathrm{a}$ & $321.1 \mathrm{a}$ & $2.1 \mathrm{a}$ & $102.8 \mathrm{a}$ & $341.8 \mathrm{a}$ & $431.1 \mathrm{a}$ & $46.1 \mathrm{~b}$ \\
\hline Summer & $140.0 \mathrm{~b}$ & $303.6 \mathrm{a}$ & $2.8 \mathrm{a}$ & $100.7 \mathrm{a}$ & $235.4 \mathrm{ab}$ & $580.7 \mathrm{a}$ & $76.8 \mathrm{ab}$ \\
\hline Autumn & $141.1 \mathrm{~b}$ & $375.7 \mathrm{a}$ & $8.6 \mathrm{a}$ & $128.6 \mathrm{a}$ & $187.8 \mathrm{~b}$ & $537.1 \mathrm{a}$ & $61.1 \mathrm{ab}$ \\
\hline \multicolumn{8}{|l|}{ Breed } \\
\hline Pantaneira & $142.3 \mathrm{a}$ & $293.0 \mathrm{a}$ & $7.0 \mathrm{a}$ & $104.1 \mathrm{a}$ & $247.0 \mathrm{a}$ & $577.7 \mathrm{a}$ & $68.9 \mathrm{a}$ \\
\hline Girolando & $166.8 \mathrm{a}$ & $349.8 \mathrm{a}$ & $3.6 \mathrm{a}$ & $99.1 \mathrm{a}$ & $260.7 \mathrm{a}$ & $494.6 \mathrm{a}$ & $65.4 \mathrm{a}$ \\
\hline Interaction & $\mathrm{P}$ value & $\mathrm{P}$ value & $\mathrm{P}$ value & $\mathrm{P}$ value & $\mathrm{P}$ value & $\mathrm{P}$ value & $\mathrm{P}$ value \\
\hline Season*Breed & $<0.05$ & $>0.05$ & $>0.05$ & $>0.05$ & $>0.05$ & $>0.05$ & $<0.05$ \\
\hline $\mathrm{CV}(\%)$ & 46.08 & 54.66 & 96.18 & 85.74 & 67.38 & 55.02 & 91.7 \\
\hline
\end{tabular}

Standing rumination (SR); lying down rumination (LDR); sleeping on foot (SF); sleeping lying down (SD); leisure (LS); eating (EAT), and social interaction (INT). Means followed by the same lowercase letters in the column do not differ by the Tukey' test at $5 \%$ probability level.

The time of standing rumination of Girolando animals was longer $(\mathrm{P}<0.05)$ in spring (Table 7). Dairy animals prefer to ruminate lying down, with the ventral part next to the ground, however they spend less time lying down when the temperature increases, and prefer standing rumination (DAMASCENO; BACCARI JÚNIOR; TARGA, 1999; SCHÜTZ et al., 2009). In this experiment, standing rumination favored thermal comfort under extreme heat as a strategy to increase surface body area and facilitate contact with winds to dissipate heat. The breeds also differed in SR in the spring season; Girolando animals spent more time ruminating standing up.
Pantaneira heifers spent more time interacting in the summer, whereas Girolando spent more time interacting in winter (Table 7). This behavior is attributed to environmental temperatures and adaptive characteristics of the breeds, with a lower heat stress and greater social interaction of Pantaneira during the summer, and a greater interaction of Girolando animals during winter when the temperatures were milder. Ferro et al. (2016) found that Nelore animals show greater social interaction and playful behaviors when managed in shady environments and with absence of thermal stress. 
P. G. L. LIMA et al.

Table 7. Unfolding of the interactions for the standing rumination and social interaction variables.

\begin{tabular}{cccc}
\hline \multirow{2}{*}{ Variables } & \multirow{2}{*}{ Season } & \multicolumn{2}{c}{ Breed } \\
\cline { 2 - 4 } & & Pantaneira & Girolando \\
\hline \multirow{3}{*}{ Standing rumination $\left(\right.$ min day $\left.^{-1}\right)$} & Winter & $107.8 \mathrm{aA}$ & $176.4 \mathrm{bA}$ \\
& Spring & $160.0 \mathrm{aB}$ & $230.0 \mathrm{aA}$ \\
& Summer & $157.8 \mathrm{aA}$ & $122.1 \mathrm{bA}$ \\
& Autumn & $143.6 \mathrm{aA}$ & $138.6 \mathrm{bA}$ \\
\hline \multirow{3}{*}{ Social interaction $\left(\right.$ min day $\left.^{-1}\right)$} & Winter & $64.3 \mathrm{bB}$ & $105.0 \mathrm{aA}$ \\
& Spring & $58.6 \mathrm{bA}$ & $53.6 \mathrm{bA}$ \\
& Summer & $100.0 \mathrm{aA}$ & $53.6 \mathrm{bB}$ \\
& Autumn & $72.8 \mathrm{bA}$ & $49.3 \mathrm{bA}$ \\
\hline
\end{tabular}

Means followed by the same lowercase letters in the columns or uppercase letters in the rows do not differ by the Tukey's test at $5 \%$ probability level.

Among the physiological dynamics, the interaction between the factors was significant only for water intake (Table 8). The number of times Pantaneira cattle searched for water was similar in all seasons. Girolando animals had greater demand for water in the summer $(\mathrm{P}<0.05)$, however, they sought for water less than Pantaneiras $(\mathrm{P}<0.05)$, except in the summer season. Thus, despite water consumption was not evaluated, it is believed that Girolando animals had a greater water intake.

Table 8. Unfolding of the interaction of the water intake variable.

\begin{tabular}{cccc}
\hline & Season & Pantaneira & Girolando \\
\hline & Winter & $1.5 \mathrm{aA}$ & $1.0 \mathrm{bB}$ \\
Water intake & Spring & $1.5 \mathrm{aA}$ & $1.1 \mathrm{bB}$ \\
(Number of times per day) & Summer & $1.3 \mathrm{aB}$ & $2.1 \mathrm{aA}$ \\
& Autumn & $1.2 \mathrm{aA}$ & $1.1 \mathrm{bA}$ \\
\hline
\end{tabular}

Means followed by the same lowercase letters in the column do not differ by the Tukey' test at $5 \%$ probability level.

Water is an important nutrient, especially during periods of thermal stress, due to its physical properties of thermal conductivity and latent heat of vaporization, which transfer heat from the animals' bodies to the environment. Increases in air temperature above the thermoneutral zone cause variations in amount of water consumed and body water loss (RASHAMOL, et al., 2018; SAIZI, MPAYIPHELI; IDOWU 2019).

Ferro et al. (2016) found a significant increase in water consumption of cattle under an intensive system with little shades, from 15.50 to 8.17 times for $0 \%$ and $80 \%$ light interception, respectively. Oliveira et al. (2015) evaluated Pantaneira heifers in a feedlot and found average water intake of 7.6 times a day, which is higher than that found in the present study on pastures (1.3 times). Water demand may be different when considering the playful behavior of the animals and, therefore, not related to water intake requirements, since animals kept in stalls and under permanent shade are not subjected to sudden changes in temperature.

The mean defection times were 2.4, 2.8, 3.8, and 2.8 in winter, spring, summer, and autumn, respectively; the highest fecal production $(\mathrm{P}<0.05)$ was found in the summer, due to the better forage quality - high leaf to stem ratio and higher $\mathrm{PB}$ and NDF concentrations - in this season (Table 1). Contrastingly, Tripon et al. (2014) evaluated dairy calves in winter and summer and found no effect of the season on defecations, with 7.8 times a day in winter and 8.2 in summer.

The Pantaneira and Girolando breeds presented no significant differences $(\mathrm{P}>0.05)$ in mean number of daily defecations, with 2.9 and 3.8 times, respectively.

Averages daily urination was 2.2, 2.7, 3.1, and 2.6 times in winter, spring, summer, and autumn, respectively; the animals urinated more frequently $(\mathrm{P}<0.05)$ in the summer due to the higher water intake, mainly Girolando heifers. The Pantaneira and Girolando breeds presented no significant differences $(\mathrm{P}>0.05)$ in mean number of daily urinations, with 2.6 and 2.7 times, respectively.

\section{CONCLUSIONS}

The preferred tree species for shading by the Girolando and Pantaneira heifers was Mangifera indica in all seasons, mainly for Girolando heifers. The feeding dynamics was similar between the breeds, however, Pantaneira heifers presented a better adaptation to the climatic conditions of the Pantanal biome and, consequently, a greater resistance to heat in the summer season, with less water demand and more time spent on social interactions.

Rev. Caatinga, Mossoró, v. 32, n. 3, p. 805 - 813, jul. - set., 2019 


\section{ACKNOWLEDGMENT}

This work was supported by CAPES, CNPq, FUNDECT, MCT, MEC, Federal Government, Pantanal Research Center (CPP) and Network PróCentro-Oeste.

\section{REFERENCES}

BALISCEI, M. A. et al. Microclimate without shade and silvopastoral system during summer and winter. Acta Scientiarum. Animal Sciences, v. 35, n. 1, p. 49-56, 2013.

BARBOSA, B. R. P. et al. Tolerância ao calor em bovinos das raças Nelore branco, Nelore vermelho e Pantaneira. Revista Brasileira de Saúde e Produção Animal, v. 15, n. 4, p. 854-865, 2014.

BIANCHINI, E. et al. Características corporais associadas com a adaptação ao calor em bovinos naturalizados brasileiros. Pesquisa Agropecuária Brasileira, v. 41, n. 9, p. 1443-1448, 2006.

BIAVATTI, H. A. Z.; BERBER, G. C. M.; BERBER, R. C. A. Produção de Leite em Sistemas Integrados. Scientific Electronic Archives, v. 7, s/n., p. 1-16, 2014.

CARVALHO, G. A. et al. Relationship between thermal comfort indices and internal temperature of grazing lactating Holstein $\times$ Gyr cows in western Amazonia. Acta Amazonica, v. 48, n. 3, p. 191-196, 2018.

DAMASCENO, J. C.; BACCARI JÚNIOR, F.; TARGA, L. A. Respostas comportamentais de vacas holandesas, com acesso à sombra constante ou limitada. Pesquisa Agropecuária Brasileira, v. 34, n. 4, p. 709-715, 1999.

DANI, S. U.; OLIVEIRA, M. V. M. Patents: Universities are right to partner. Nature, v. 502, n. 7472, p. 448, 2013.

DE MORAES, A. L. Suplementação de bovinos de corte em sistema de pastejo. Ensaios e Ciência: Ciências Biológicas, Agrárias e da Saúde, v. 16, n. 5, p. 97-112, 2012.

DE OLIVEIRA, C. C. et al. Thermal comfort indices assessed in integrated production systems in the Brazilian savannah. Agroforestry systems, v. 92, n. 6, p. 1659-1672, 2018.

FACURI, L. M. et al. Ingestive behavior of heifers supplemented with glycerin in substitution of corn on Brachiaria brizantha pasture. AsianAustralasian Journal of Animal Sciences, v. 27, n. 11, p. $1584-1592,2014$.

FERRO, D. A. C. et al. Physiological and behavioral responses of Nellore steers to artificial shading in an intensive production system. Semina: Ciências Agrárias, v. 37, n. 1, p. 2785-2792, 2016.

GARRY, L. A., SHERRITT, G. W., HALE, E. B. Behavior of Charolais cattle on pasture. Journal of Animal Science, v. 30, n. 2, p. 303-306, 1970.

GREGORINI, P. et al. Effect of herbage depletion on short-term foraging dynamics and diet quality of steers grazing wheat pastures. Journal of Animal Science, v. 89, n. 11, p. 3824-3830, 2011.

KARVETTE, J. N. et al. Shading effect on microclimate and thermal comfort indexes in integrated crop-livestock-forest systems in the Brazilian Midwest. International Journal of Biometeorology, v. 60, n. 12, p. 1933-1941, 2016.

LEME, T. M. S. P. et al. Comportamento de vacas mesticas holandes $\mathrm{x}$ zebu, em pastagem de Brachiaria decumbens em sistema silvipastoril. Ciência Agrotecnologia, v. 29, n. 3, p. 668-675, 2005.

LESS, A. M. et al. Effect of heat stress on rumen temperature of three breeds of cattle. International Journal of Biometeorology, v. 62, n. 2, p. 207-215, 2018.

LOUREIRO, V. R.; BARBOSA, E. J. S. Cidade de Belém e natureza: uma relação problemática?. Novos Cadernos NAEA, v. 13, n. 1, p. 105-134, 2010.

NEPOMUCENO, C. F. et al. Controle de absição foliar e morfogênese in vitro em culturas de Anadenanthera colubrina (Vell.) Brenan var. cebil (Griseb) Altschul. Revista Árvore, v. 31, n. 5, p. 967 $-975,2007$.

OLIVEIRA, M. V. M. et al. Comportamento ingestivo de novilhas Pantaneiras mantidas em regime de confinamento. Revista Brasileira de Saúde e Produção Animal, v. 16, n. 3, p. 688-698, 2015.

OTSUBO, H. C. B. et al. Variação genética para caracteres silviculturais em três espécies arbóreas da região do bolsão Sul-mato-grossense. Cerne, v. 21 n. 4 , p. 535-544. 2015.

PAULA, E. J. H. et al. Simulação dos impactos da seleção para crescimento e habilidade materna sobre a eficiência reprodutiva de um rebanho Nelore. Revista Brasileira de Saúde e Produção Animal, v. 11, n. 3, p. 641-650, 2010. 
PROHMANN, P. E. F. et al. Método de amostragem e caracterização química da forragem consumida por bovinos em pasto consorciado de aveia e azevém. Arquivo Brasileiro de Medicina Veterinária e Zootecnia, v. 64, n. 4, p. 953-958, 2012.

$\mathrm{R}$ Development Core Team. A language and environment for statistical computing. $R$ Found. Stat. Comput. 2016.

RASHAMOL, V. P. et al. Physiological adaptability of livestock to heat stress: an updated review. Journal of Animal Behaviour and Biometeorology, v. 6, n. 3, p. 62-71, 2018.

RODRIGUES, A. L.; SOUZA, B. B.; PEREIRA FILHO, J. M. Influência do sombreamento e dos sistemas de resfriamento no conforto térmico de vacas leiteiras. Agropecuária Científica no SemiÁrido, v. 6, n. 2, p. 14-22, 2010.

SAIZI, T.; MPAYIPHELI, M.; IDOWU, P. A. Heat tolerance level in dairy herds: a review on coping strategies to heat stress and ways of measuring heat tolerance. Journal of Animal Behaviour and Biometeorology, v. 7, n. 2, p. 39-51, 2019.

SCHÜTZ, K. E. et al. Dairy cows prefer shade that offers greater protection against solar radiation in summer: Shade use, behaviour, and body temperature. Applied Animal Behaviour Science, v. 116, n. 1, p. 28-34, 2009.

SHIOTA, Á. M. et al. Parâmetros fisiológicos, características de pelame e gradientes térmicos em novilhas nelore no verão e inverno em ambiente tropical. Bioscience Journal, v. 29, n. 1, p. 16871695, 2013.

SILVA, T. P. D. E et al. Efeito da exposição à radiação solar sobre parâmetros fisiológicos e estimativa do declínio na produção de leite de vacas mestiças (Holandês X Gir ) no sul do estado do Piauí. Comunicata Scientiae, v. 3, n. 4, p. 299-305, 2012.

TRIPON, I. et al. Effects of seasonal and climate variations on calves' thermal comfort and behaviour. International Journal of Biometeorology, v. 58, n. 7, p. 1471-1478, 2014.

VAN SOEST, P. J. Nutritional ecology of the ruminant. 2.ed. Ithaca: Cornell University Press, 1994. $476 \mathrm{p}$.

VILELA, L. et al. Sistemas de integração lavoura pecuária na região do Cerrado. Pesquisa Agropecuária Brasileira, v. 46, n. 10, p. $1127-$
$1138,2011$. 